\title{
Factors Associated with Initial Public School Reopening Plans During the US COVID-19 Pandemic: a Retrospective Study
}

J Gen Intern Med 36(3):852-4

DOI: $10.1007 / \mathrm{s} 11606-020-06470-1$

(C) This is a U.S. government work and not under copyright protection in the U.S.; foreign copyright protection may apply 2021

\section{INTRODUCTION}

Because of the novel coronavirus disease 2019 (COVID-19), all 50 states closed public schools by April 2020 for the remainder of the academic year to mitigate COVID-19 transmission. School reopening decisions for the 2020-2021 academic year were delegated to states and local districts. Reopening options include full on-site learning, hybrid approaches with mixed remote and in-person learning, and remote-only learning. ${ }^{1}$ Lacking robust evidence, decisionmakers weighed the risks of exposing students and staff to COVID-19 with the benefits of in-person school, including superior academic outcomes and the provision of essential services, such as nutrition and childcare. ${ }^{2,3}$

Identifying factors that influenced school reopening decisions early in the academic year will allow policymakers and communities to understand the extent to which community COVID-19 prevalence and other characteristics informed reopening strategies. Officials are frequently re-evaluating strategies and incorporating evidence as knowledge increases about the virus and the impacts of different mitigation strategies. The North Carolina (NC) Governor announced on July 14,2020 , that districts could select between modified onsite learning (hybrid) and remote learning-only options. ${ }^{1}$ Using NC as a case study, we characterize the COVID-19 burden, school, and county characteristics associated with initial school district 2020-2021 reopening decisions.

\section{METHODS}

In this retrospective study using public data, the primary outcomes are initial school district reopening decisions (hybrid versus remote) and the initial duration of remote learning (number of weeks). Districts not reporting duration $(n=7)$ were excluded from the duration analysis. Predictors included county COVID-19 burden (new cases July 15 to July 31,

Received October 13, 2020

Accepted December 13, 2020

Published online January 19, 2021
2020, and cumulative deaths as of July 31, 2020); school district characteristics (size, student/teacher ratio, academic performance, and proportion of students eligible for free and reduced lunch); and county-level characteristics (population, race/ethnicity, rurality) and county political preference (binary indicator for above versus below the median percent of 2016 vote for republican presidential nominee). Binary and count outcomes were modeled using logistic and Poisson distributions in Stata 16.0. The study was exempted by the Duke University Institutional Review Board.

\section{RESULTS}

Among the $115 \mathrm{NC}$ school districts, 50 (43\%) initially selected hybrid learning approaches for the 2020-2021 academic year. Of the $65(57 \%)$ selecting initial remote-only learning, 32 plan to reopen or reassess in less than 9 weeks (Tables 1 and 2).

In adjusted analysis, race and political preference were significantly associated with both the probability and duration of remote-only learning. School districts in counties with a high proportion (top quartile) of Black residents had increased odds (odds ratio $[\mathrm{OR}]=5.3,95 \%$ confidence interval $[\mathrm{CI}]=$ $1.0,26.8)$ and longer duration $(2.3$ weeks longer $\mathrm{CI}=1.1,3.6)$ of remote learning, while Republican voting areas had decreased odds $(\mathrm{OR}=0.2, \mathrm{CI}=0.1,0.7)$ and shorter duration (3.8 weeks shorter, $\mathrm{CI}=-4.6,-2.9$ ) of remote-only learning. County COVID-19 case and death rates were not significantly associated with the odds of remote-only learning. For districts starting as remote-only, higher local COVID-19 cumulative death rates were associated with longer duration, while higher 14-day case rates were associated with shorter duration of remote learning. Larger proportions of students receiving free/reduced lunch were associated with shorter remote learning duration.

\section{DISCUSSION}

The inconsistent association of the local COVID-19 burden with school reopening plans suggests that epidemiologic data is not driving schools' decision-making. Only in mid-September were indicators and thresholds released by the Centers for Disease Control and Prevention, guidance that was lacking when most schools were making their initial reopening 
Table 1 COVID-19, School District, and County Characteristics by Initial School Reopening Plan (as of August 12, 2020), North Carolina

\begin{tabular}{|c|c|c|c|}
\hline & $\begin{array}{l}\text { Hybrid } \\
\text { learning }(N \\
=50) \text {, mean } \\
\text { (SD) }\end{array}$ & $\begin{array}{l}\text { Remote } \\
\text { learning: }<9 \\
\text { weeks }(N=32), \\
\text { mean }(\text { SD) }\end{array}$ & $\begin{array}{l}\text { Remote } \\
\text { learning: } \geq 9 \\
\text { weeks }(N= \\
\text { 33), mean } \\
\text { (SD) }\end{array}$ \\
\hline \multicolumn{4}{|c|}{ County COVID-19 burden } \\
\hline $\begin{array}{l}\text { Incident cases } \\
\text { per } 100,000\end{array}$ & $\begin{array}{l}286.7 \\
(155.0)\end{array}$ & 291.5(112.1) & $270.3(121.1)$ \\
\hline $\begin{array}{l}\text { Cumulative } \\
\text { deaths per } \\
100,000\end{array}$ & $15.3(16.6)$ & 20.1(14.6) & $24.7(21.8)$ \\
\hline \multicolumn{4}{|c|}{ School district characteristics } \\
\hline $\begin{array}{l}\text { Size, \% (n) } \\
\text { Small }(<5000 \\
\text { students) }\end{array}$ & $48.0(24)$ & $31.3(10)$ & $48.5(16)$ \\
\hline $\begin{array}{l}\text { Medium } \\
\text { (5000-15,000 } \\
\text { students) }\end{array}$ & $22.0(11)$ & $28.1(9)$ & $27.3(9)$ \\
\hline $\begin{array}{c}\text { Large (> } \\
15,000 \text { students) }\end{array}$ & $30.0(15)$ & $40.6(13)$ & $24.2(8)$ \\
\hline $\begin{array}{l}\text { Student/teacher } \\
\text { ratio }\end{array}$ & $14.7(1.2)$ & $15.3(1.2)$ & $14.4(1.1)$ \\
\hline $\begin{array}{c}\text { Met academic } \\
\text { standards, \% (n) }\end{array}$ & $98.0(49)$ & $93.8(30)$ & $84.8(28)$ \\
\hline $\begin{array}{l}\text { Proportion of } \\
\text { students eligible } \\
\text { for free/reduced } \\
\text { lunch }\end{array}$ & $0.65(0.18)$ & $0.72(0.21)$ & $0.71(0.24)$ \\
\hline \multicolumn{4}{|c|}{ County characteristics } \\
\hline $\begin{array}{l}\text { Population in } \\
1000 \mathrm{~s}\end{array}$ & $79.4(69.3)$ & $157.4(250.6)$ & $97.2(118.5)$ \\
\hline $\begin{array}{l}\text { Race/ethnicity } \\
\text { Proportion } \\
\text { Black population }\end{array}$ & $0.13(0.11)$ & $0.20(0.14)$ & $0.30(0.20)$ \\
\hline $\begin{array}{l}\text { Proportion } \\
\text { Hispanic } \\
\text { population }\end{array}$ & $0.06(0.03)$ & $0.08(0.04)$ & $0.06(0.03)$ \\
\hline Rural, \% (n) & $56.0(28)$ & $43.8(14)$ & $54.5(18)$ \\
\hline $\begin{array}{l}\text { Republican } \\
\text { voting } \\
\text { preference, \% (n) }\end{array}$ & $65.3(33)$ & $59.3(19)$ & $45.8(15)$ \\
\hline
\end{tabular}

$S D$ standard deviation

As of the start of the 2020-2021 school year, North Carolina state policy did not allow public schools to reopen with fulltime in-person instruction for all students (plan A), but did allow public schools to open under plans using a hybrid of in-person and remote learning to increase social distancing (plan B) or remote-only instruction (plan C). Data sources included the New York Times COVID-19 database, National Center for Education Statistics, North Carolina Department of Public Instruction; Area Health Resource File; and the National Public Radio records (voting preference)

decisions. ${ }^{4}$ Additionally, administrators considered parent and staff perspectives as well as economic impacts, which may have outweighed the potential COVID-19 risks of in-person learning. In the absence of standardized reopening criteria, political preferences appeared to be a factor driving school decision-making in NC. While a single state analysis may limit generalizability, all but four states allowed school districts and local health authorities the flexibility to choose between remote-only and some form of on-site learning. ${ }^{5}$

In-person learning offers benefits for both children and families, including academic and social emotional well-being. The sociodemographic factors, such as Black race and free lunch eligibility, associated with remote learning choices raise further concerns about worsening already substantial academic inequities or exacerbating the disproportionate burden of
Table 2 COVID-19, School District, and County Characteristics Associated with Initial School Reopening Plan (as of August 12, 2020), North Carolina

\begin{tabular}{|c|c|c|}
\hline & $\begin{array}{l}\text { Odds of remote } \\
\text { learning }\end{array}$ & $\begin{array}{l}\text { Duration of } \\
\text { remote learning }\end{array}$ \\
\hline & Odds ratio $(\mathrm{CI})$ & $\begin{array}{l}\text { Change in weeks } \\
\text { (CI) }\end{array}$ \\
\hline \multicolumn{3}{|l|}{ County COVID-19 burden } \\
\hline $\begin{array}{l}\text { Incident cases per } 1000 \\
\text { residents }\end{array}$ & $0.7(0.5,1.1)$ & $\begin{array}{l}\dagger-0.5(-0.9,- \\
0.1)\end{array}$ \\
\hline Cumulative deaths per & $7.7(0.3,176.6)$ & $3.6(1.6,5.5)$ \\
\hline 1000 residents & & \\
\hline \multirow{2}{*}{\multicolumn{3}{|c|}{ School district characteristics }} \\
\hline \multicolumn{2}{|l|}{ Size } & \\
\hline Small (< 5000 students $)$ & Ref & Ref \\
\hline Medium $(5000-15,000$ & $1.4(0.4,4.4)$ & $-0.4(-1.3,0.6)$ \\
\hline students) & & \\
\hline $\begin{array}{c}\text { Large } \\
\text { students) }\end{array}$ & $1.0(0.3,3.5)$ & $-0.4(-1.5,0.7)$ \\
\hline Student/teacher ratio & $1.2(0.4,3.5)$ & $-0.0(-1.1,1.1)$ \\
\hline Met academic standards & $0.3(0.0,4.8)$ & $-1.7(-3.6,0.2)$ \\
\hline Free/reduced lunch eligi- & $0.6(0.0,9.1)$ & $\dagger-4.1(-6.6,-$ \\
\hline bility (proportion) & & 1.6) \\
\hline \multicolumn{3}{|l|}{ County characteristics } \\
\hline $\begin{array}{l}\text { Top quartile Black } \\
\text { population }\end{array}$ & $* 5.3(1.0,26.8)$ & ${ }^{\ddagger} .3(1.1,3.6)$ \\
\hline $\begin{array}{l}\text { Top quartile Hispanic } \\
\text { population }\end{array}$ & $1.6(0.5,4.8)$ & $0.1(-0.8,1.1)$ \\
\hline Rural & $0.5(0.2,1.5)$ & $-0.6(-1.6,0.3)$ \\
\hline Top quartile Republican & ${ }^{\dagger} 0.2(0.1,0.7)$ & $3.8(-4.6,-$ \\
\hline vote & & 2.9) \\
\hline
\end{tabular}

COVID-19 impacts on Black and Latinx communities. ${ }^{6}$ Safeguarding the well-being of children, school staff, and communities equitably requires clear guidance and evidencebased decisions by schools.

Brystana G. Kaufman, $P h D, M S P H^{1,2,3}$

Nirosha Mahendraratnam, $P h D^{1}$

Thuy-vi Nguyen, $B A^{1}$

Laura Benzing, BS expected 2021 ${ }^{1}$

Jessica Beliveau, $M P H^{1}$

Christina Silcox, $P h D^{1}$

Charlene A. Wong, MD, MSHP (masters of science in health policy) $)^{1,4,5,6}$

${ }^{1}$ Margolis Center for Health Policy, Duke University, Durham, NC, USA

${ }^{2}$ Population Health Sciences, Duke University School of Medicine,

Durham, NC, USA

${ }^{3}$ Center of Innovation to Accelerate Discovery and Practice Transformation (ADAPT), Durham VA Medical Center,

Durham, NC, USA

${ }^{4}$ Department of Pediatrics, Children's Health and Discovery Initiative, Duke University School of Medicine,

Durham, NC, USA

${ }^{5}$ Sanford School of Public Policy, Duke University, Durham, NC, USA

${ }^{6}$ Duke Clinical Research Institute, Duke University School of Medicine,

Durham, NC, USA 
Corresponding Author: Brystana G. Kaufman, PhD, MSPH; Margolis Center for Health Policy, Duke University, Durham, NC, USA (e-mail: Brystana.kaufman@duke.edu).

Author Contributions Brystana Kaufman made substantial contribution(s) to the conception and design, acquisition of data, and analysis and interpretation of data; and drafting the article and revising it critically for important intellectual content; and final approval of the version to be published, and agrees to be accountable for all aspects of the work in ensuring that questions related to the accuracy or integrity of any part of the work are appropriately investigated and resolved.

Nirosha Mahendraratnam made substantial contribution(s) to the conception and design, acquisition of data, and analysis and interpretation of data; and revising the article critically for important intellectual content; and final approval of the version to be published, and agrees to be accountable for all aspects of the work in ensuring that questions related to the accuracy or integrity of any part of the work are appropriately investigated and resolved.

Thuy-vi Nguyen made substantial contribution(s) to the conception and design, acquisition of data, and interpretation of data; and drafting the article and revising it critically for important intellectual content; and final approval of the version to be published, and agrees to be accountable for all aspects of the work in ensuring that questions related to the accuracy or integrity of any part of the work are appropriately investigated and resolved.

Laura Benzing made substantial contribution(s) to the acquisition of data and interpretation of data; and revising the article critically for important intellectual content; and final approval of the version to be published, and agrees to be accountable for all aspects of the work in ensuring that questions related to the accuracy or integrity of any part of the work are appropriately investigated and resolved.

Jessica Beliveau made substantial contribution(s) to the acquisition of data and interpretation of data; and revising the article critically for important intellectual content; and final approval of the version to be published, and agrees to be accountable for all aspects of the work in ensuring that questions related to the accuracy or integrity of any part of the work are appropriately investigated and resolved.

Christina Silcox made substantial contribution(s) to the conception and design, acquisition of data, and interpretation of data; and revising the article critically for important intellectual content; and final approval of the version to be published, and agrees to be accountable for all aspects of the work in ensuring that questions related to the accuracy or integrity of any part of the work are appropriately investigated and resolved.
Charlene Wong made substantial contribution(s) to the conception and design, acquisition of data, and analysis and interpretation of data; and drafting the article and revising it critically for important intellectual content; and final approval of the version to be published, and agrees to be accountable for all aspects of the work in ensuring that questions related to the accuracy or integrity of any part of the work are appropriately investigated and resolved.

\section{Compliance with Ethical Standards:}

Conflict of Interest: The authors declare that they do not have a conflict of interest. Charlene Wong began contract work with the North Carolina Department of Health and Human Services after the primary work on this study was completed.

\section{REFERENCES}

1. North Carolina Department of Health and Human Services. Strong Schools NC Public Health Toolkit (K-12). 2020. https://files.nc.gov/covid/documents/guidance/Strong-Schools-NC-Public-Health-Toolkit.pdf. Accessed 27 Sept 2020

2. Auger KA, Shah SS, Richardson T, et al. Association Between Statewide School Closure and COVID-19 Incidence and Mortality in the US. JAMA. 2020;324(9):859-870. doi:https://doi.org/10.1001/jama.2020. 14348\%JJAMA

3. Allison MA, Attisha E. The Link Between School Attendance and Good Health. Pediatrics. 2019;143(2). doi:https://doi.org/10.1542/peds.20183648

4. Centers for Disease Control and Prevention. CDC indicators and thresholds for risk of introduction and transmission of COVID-19 in schools. https://www.cdc.gov/coronavirus/2019-ncov/community/schoolschildcare/indicators.html\#thresholds. Accessed 27 Sept 2020

5. State-by-State Map of Where School Buildings Are Opened or Closed. Education Week. https://www.edweek.org/ew/section/multimedia/mapcovid-19-schools-open-closed.html. Accessed 27 Sept 2020

6. Hooper MW; Pérez-Stable EJ. COVID-19 and Racial/Ethnic Disparities. JAMA. 2020;323(24):2466-2467.

Publisher's Note: Springer Nature remains neutral with regard to jurisdictional claims in published maps and institutional affiliations. 